\title{
COMPARISON THE NUMBER OF BACTERIA BETWEEN WASHING HANDS USING SOAP AND HAND SANITIZER AS A BACTERIOLOGY LEARNING RESOURCE FOR STUDENTS
}

\author{
Satya Darmayani*, Askrening, Apita Ariyani \\ Department of Medical Laboratory Technology, Health Polytechnic of Kendari, Indonesia \\ *corresponding e-mail: satya.darmayani@gmail.com
}

\begin{abstract}
Hands are the principal carriers of bacterial diseases, therefore very important to know that washing hands with soap or hand sanitizer is highly effective healthy behaviors to reduce bacteria in the palm. This study aimed to determine the total number of bacteria between washing hands with soap and hand sanitizer, also applying the results of these studies as a learning resource in bacteriology. The research design was the true experiment with pretest-posttest control group research design and laboratory examination. Analysis of data using paired t-test and independent sample t-test with $\alpha=0.05$. The result using paired t-test obtained $t$ count $=2.48921>t 0.05(14)=2.14479$ (with liquid soap), obtained $t$ count $=2.32937>t 0.05(14)=2.14479$ (with hand sanitizer). As for the comparison of the total number of bacteria include washing hands with soap and hand sanitizer using independent samples $t$-test obtained results there were differences in the total number of bacteria include washing hands with liquid soap and hand sanitizer with $t$ count $=2.23755>t$ $0.05(13)=2.16037$. That results showed hand sanitizer more effective to reduce the number of bacteria than the liquid soap, that was hand sanitizer $96 \%$ and liquid soap by $95 \%$.
\end{abstract}

Keywords: Hand sanitizer, liquid soap, total number of bacteria

(C) 2017 Department of Biology Education, FTTE, University of Muhammadiyah Malang, Indonesia

\section{INTRODUCTION}

Everyone wants a healthy situation in their life activities, it is necessary to maintain and improve their own health (Indan, 2010). One way to support these efforts is to maintain personal hygiene, namely the behaviour of individuals to maintain personal hygiene in many of their daily activities. Public awareness of personal hygiene is increasing following the availability of products antiseptic for maintaining or improving personal hygiene. They support the change of healthy and clean living behaviour. In moslem perspective in the hadith of the Prophet SAW, narrated from Sa'd bin Abi Waqas from his father, Rasulullah said: "Indeed Allah is holy who loves holy things, Allah is clean who likes cleanliness, Allah is noble who likes glory, Allah is beautiful who loves beauty, because it, clean your places".

Formative study results about hygiene behavior held by water and sanitation program showed the behavior of washing hands using soap has not become yet common practice in society (USAID, 2006) and the national prevalence rate behaves properly in washing hands about proper hand washing was $23.2 \%$ (Ministry of Health Republic of Indonesia, 2008). Indonesian people's habits in washing hands with soap is relatively low. This indication can be seen by the high prevalence of diarrheal diseases (Ministry of Health Republic of Indonesia, 2008) and recorded average only $12 \%$ of people who do wash their hands with soap (Ministry of Health Republic of Indonesia, 2010).

Hand hygiene is also required for health workers in treating patients (Murray, 2005). Hands are the main carriers of bacteria causing diseases such as Salmonella sp and Escherichia coli. Therefore it is very important to know and remember that washing hand with soap is healthy behaviours and highly effective to preventing the spread of various infectious diseases such as diarrhea, respiratory infections, and avian influenza (Wati, 2011; WHO, 2009). The above mentioned diseases can be avoided by washing hands with soap or antiseptic which is a simple, easy to do, no need to spend much time and money (Sibuea, 2007). 
Along with increasing busyness of people, especially in urban areas, and the number of instant products which fast paced and practical, it appears the product innovation waterless hand sanitizers known antiseptic hand cleaner or hand sanitizer. This product contains antiseptic hand sanitizers are used to kill bacteria in the hand, which is composed of alcohol and triclosan. Even this type of hand sanitizer products are also increasingly diverse, both in composition, the carrier substance, and has marketed new products that are used widely in society (Desiyanto \& Djannah, 2013; Wahdiniati, 2016).

The result of shows that there was a difference in the total number of bacteria between washing hands with flowing water, soap, hand sanitizer A, hand sanitizer B, and a control group (without washing hands). Antiseptic hand sanitizers is effective against bacteria and decrease the number of figures is descriptive of the most effective is the hand sanitizer B (alcohol 60\%).

Quantitative methods are used to determine the number of microbes, generally known as total plate count. The total plate test and more precisely the mesophyll aerobic or mesophyll anaerob using solid media with the end result are visually observable colonies of colonic numbers per $\mathrm{ml}$ or per gram or colony $/ 100 \mathrm{~mL}$. The means used among others by means of casting, the way drops and dispersive manner (Desiyanto \& Djannah, 2013).

The development of creativity in teaching is one important factor in the ongoing learning process. Learning resource is anything that can provide convenience to learners in obtaining some information, knowledge, experience and skills in the learning process (Purwatiningsih, 2015; Retno, 2016).

Based on need assessment conducted on student of Medical Laboratory Technology Department, Health Polytechnic of Kendari found that the student has some awareness of hygiene by washing hands. $97.5 \%$ of 120 respondents had a habit of washing hands and $2.5 \%$ do not have awareness about cleanliness, based on the questionnaire there were accustomed to washing hands with soap and some use hand sanitizer (March, 2017).

According to the description above, it is necessary to conduct further research on the comparison of the total number of bacteria includes washing hands with soap and hand sanitizer. The result can be used as a learning resource for students at Health Polytechnic of
Kendari, Medical Laboratory Technology Department in Course.

\section{METHOD}

This study was conducted on 07-18 July 2017 at the Laboratory of Health, Medical Laboratory Technology Department, Health Polytechnic of Kendari. This type of research done in true experimental with research design pretestposttest control group that is the difference of the total number of bacteria between washing hands with soap and hand sanitizer at Medical Laboratory Technology Department, Health Polytechnic of Kendari. The amount of sample as many as 30 students of Laboratory of Health, Medical Laboratory Technology Department, Health Polytechnic of Kendari. Department consisting of 15 students in grade I and grade II with 15 students with stratified random sampling as sampling techniques. If the population is $>100$ then the sample is taken $15-30 \%$ and if the population is $<100$ then the sample is taken 2550\% (Notoatmodjo, 2015; Shu, 2013).

The data in this study were collected from the beginning of the research, namely data collection using questionnaires, journals, books or literature supporting research. Sampling palms of the student at Medical Laboratory Technology Department, Health Polytechnic of Kendari before and after washing hands with soap and hand sanitizer. Then examined by Total Plate Number Method. The results are then processed and reported as research data.

\section{Tools and Materials}

Tools used in this research were reaction tubes and tube racks, measuring pipette $\mathrm{ml}$ and $5 \mathrm{ml}$, stirring rod, methanol lamps, cotton, inoculating loop, graduated cylinder, incubator and petri dish.

The materials used in this study is liquid soap, hand sanitizer, $\mathrm{NaCl}$ sterile $0.9 \%$, aquades and petri medium of NA (Nutrient Agar).

\section{Data Analysis}

Data were analysed by a univariate analysis using the paired t-test to compare the mean of the sample pairs to compare the total number of bacteria before and after washing hands with liquid soap and hand sanitizer. Where: $t$ count $>t$ $\mathrm{tab}=$ different significance $\left(\mathrm{H}_{0}\right.$ rejected $)$ and $\mathrm{t}$ count $<\mathrm{t} t a b=$ Not different significance $\left(\mathrm{H}_{0}\right.$ accepted). While independent sample t-test was used to compare the two groups of the mean of 
two different samples that is used to compare the total number of bacteria between wash hands with soap and hand sanitizer in students of Medical Laboratory Technology Department, Health Polytechnic of Kendari. Where: $t$ hit $>t$ $\mathrm{tab}=$ different significance $\left(\mathrm{H}_{0}\right.$ rejected $)$ and $\mathrm{t}$ count $<\mathrm{t}$ tab $=$ Not different significance $\left(\mathrm{H}_{0}\right.$ accepted). Level of the significance $(\alpha): 0.05$.

a. Paired T test

Formula:

$$
\begin{aligned}
& \mathrm{t}_{\text {hit }}=\frac{\bar{D}}{\frac{S D}{\sqrt{n}}} \\
& \mathrm{SD}=\sqrt{\text { variance }} \\
& \text { Variance }\left(s^{2}\right): \\
& \frac{1}{n-1} \sum_{i=1}^{n}((\mathrm{x} 1-\mathrm{x} 2)-\bar{D})^{2}
\end{aligned}
$$

Explanation:

$\mathrm{t}_{\text {count }}=$ value of $\mathrm{t}$ count

$\bar{D}=$ average difference in measurements 1 and 2

$\mathrm{SD}=$ standard deviation of difference in measurements 1 and 2

$\mathrm{n}=$ number of samples

Interpretation:

a. To interpret the test of t-test (paired t-test) must first be determined:

The significance value $\alpha=0,05$. Level of confidence $95 \%$

df (degree of freedom) for t paired, $\mathrm{df}=\mathrm{n}-1$

b. Compare the value of the $t$ count and $t a b=$ $\alpha:(n-1)$

c. If:

$\mathrm{t}$ count $>\mathrm{t}$ tab $=$ Significantly different $\left(\mathrm{H}_{0}\right.$ rejected)

$\mathrm{t}$ count $<\mathrm{t}$ tab $=$ Not significantly different $\left(\mathrm{H}_{0}\right.$ accepted)

b. Independent Sample t- test

Formula:

$$
\begin{aligned}
& \mathrm{t}_{\text {count }}=\frac{M 1-M 2}{\sqrt{\frac{5 S_{1}+S S_{2}}{\mathrm{n}_{1}+\mathrm{n}_{2}-2}\left(\frac{1}{\mathrm{n}_{1}}+\frac{1}{\mathrm{n}_{2}}\right)}} \\
& \mathrm{M}_{1}=\frac{\sum \mathrm{X}_{1}}{\mathrm{n}_{1}} \\
& \mathrm{M}_{2}=\frac{\sum \mathrm{X}_{2}}{\mathrm{n}_{2}} \\
& S S_{1}=\sum \mathrm{X}_{1}^{2}-\frac{\left(\sum \mathrm{X}_{1}\right)^{2}}{\mathrm{n}_{1}} \\
& S S_{2}=\sum \mathrm{X}_{2}^{2}-\frac{\left(\sum \mathrm{X}_{2}\right)^{2}}{\mathrm{n}_{2}}
\end{aligned}
$$

Explanation:

M1 = average score of group 1

M2 = average score of group 2
SS1 = sum of square group 1 / Number of squares of groups 1

$\mathrm{SS} 2=$ sum of square group 2 / Number of squares of group 2

$\mathrm{n} 1=$ number of subject/ sample group 1

$\mathrm{n} 2=$ number of subject/ sample group 2

Interpretation:

a. To interpret the independent sample of ttest must first be determined:

The significance level $\alpha=0,05$. The level of confidence is $95 \%$.

df (degree of freedom) for $\mathrm{t}$ paired, $\mathrm{df}=\mathrm{n}-2$.

b. Compare the value of the $t_{\text {count }}$ by $t_{t a b}=\alpha$ : $(n-2)$

c. If:

$\mathrm{t}$ count $>\mathrm{t}$ tab $=$ Significantly different $\left(\mathrm{H}_{0}\right.$ rejected)

$\mathrm{t}$ count $<\mathrm{t}$ tab $=$ Not significantly different $\left(\mathrm{H}_{0}\right.$ accepted).

\section{RESULTS AND DISCUSSION}

\section{Number of bacteria before and after washing hands using liquid soap}

In studies comparing the total number of bacteria include washing hands with soap and hand sanitizer in student of Medical Laboratory Technology Department, Health Polytechnic of Kendari, conducted on 30 palms respondent of students were divided into two groups, namely group A is 15 respondents hands of students before and after washing hands with liquid soap and group B consisted of 15 respondents before and after washing hands using hand sanitizer. The research was conducted in true experimental using the pretest-posttest control group as the research design in which this study aimed to compare the results of the total number of bacteria include washing hands with liquid soap and hand sanitizer on students.

The result of a univariate analysis in group A before and after washing hands using liquid soap on students of medical laboratory technology department who total 15 respondents palms obtained an average total number of bacteria before washing hands was 5,162,000 colonies per $\mathrm{mL}$, and after washing hands using the liquid soap that was 615,667 colonies per $\mathrm{mL}$. The decline in the total number of colonies of 
bacteria that was as much as $4,887,500$ per $\mathrm{mL}$ or $95 \%$.

Table 1. Result of univariate analysis group A (before and after hand washing using liquid soap)

\begin{tabular}{lccc}
\hline \multirow{2}{*}{ No. } & \multicolumn{3}{c}{ Number of Bacteria } \\
\cline { 2 - 4 } Sample & Before & After & Difference \\
\hline 1. & 500,000 & 730,000 & $-230,000$ \\
2. & $3,800,000$ & $1,925,000$ & $1,875,000$ \\
3. & $4,900,000$ & 480,000 & $4,420,000$ \\
4. & $1,140,000$ & 70,000 & $1,070,000$ \\
5. & 350,000 & $3,000,000$ & $-2,650,000$ \\
6. & $11,200,000$ & 760,000 & $10,440,000$ \\
7. & 0 & 0 & 0 \\
8. & 0 & 0 & 0 \\
9. & $3,595,000$ & 0 & $3,595,000$ \\
10. & $22,900,000$ & 0 & $22,900,000$ \\
11. & $1,060,000$ & 0 & $1,060,000$ \\
12. & $10,300,000$ & 0 & $10,300,000$ \\
13. & $16,945,000$ & $1,960,000$ & $14,985,000$ \\
14. & 320,000 & 0 & 320,000 \\
15. & 420,000 & 310,000 & 110,000 \\
\hline Amount & $283,530,000$ & $9,235,000$ & $274,295,000$ \\
\hline Averag & $5,162,000$ & 615,667 & $4,887,500$ \\
\hline Source: Primary Data, 2017) &
\end{tabular}

Based on the results of the bivariate analysis in table 1 was obtained $\mathrm{t}$ count $=2.48921>\mathrm{t} 0.05(14)=2.14479$ concluded to reject $\mathrm{H} 0$, meaning that there were differences in the total number of bacteria before and after washing hands with liquid soap. Based on the results of the study (Rachmawati, 2008; Sunarti, 2015) stated that using hand washing soap can reduce the number of bacteria on the palms of visitors in the library of the decline of $50-100 \%$. So washing hands with soap effectively reduce the number of germs in the palm of visitors of the library. Based on that opinion there is similarity of research result, namely soap is effective to decrease the amount of bacteria number.

As for what causes an increase in the number of bacteria after washing hands on a sample number 1 is 730,000 colonies per $\mathrm{mL}$ and 5 at 3,000,000 colonies per $\mathrm{mL}$ who use liquid soap caused by students after washing hands is not intentionally holding the surrounding objects so that bacteria in the body stick back on the palms and therefore the number of bacteria more than before washing hands with liquid soap.
Liquid soap is useful to kill or reduce the number of microorganisms because it contains substances disinfectant, so that the treatment using liquid soap, obtained a lower number of bacterial numbers than before washing hands. Wash hands before and after the activity are important because it is a very effective health practices to prevent the spread of various infectious diseases such as diarrhea, respiratory infections, and avian influenza. The above-mentioned diseases can be avoided by hand washing with soap or antiseptic which is a simple, easy to do the behaviour, no need to spend much time and money (Qisti et al., 2009; Sibuea, 2007).

\section{Total score bacteria before and after washing hands using hand sanitizer}

Results of univariate analysis group B before and after washing hands with hand sanitizer in students at Health Polytechnic of Kendari, Medical Laboratory Technology Department totalling 15 palms of respondents obtained average the total number of bacteria before washing hands is $1,314,000$ colonies per $\mathrm{mL}$ and after washing hands, namely 58,667 colonies every $\mathrm{mL}$. The decrease of bacterial number is $1,255,333$ colonies per $\mathrm{mL}$ or $96 \%$.

Based on the results of the bivariate analysis using a paired t-test resulted in $\mathrm{t}$ count $=2.32937>$ t $0.05(14)=2.14479$ concluded to reject $\mathrm{H} 0$, meaning that there were differences in the total number of bacteria before and after washing hands using hand sanitizer. These results are consistent with research (Shu, 2013) stated preparations with a hand sanitizer gel with carbomer base that contained alcohol $42 \%$ can reduce the number of bacteria on the left thumb $35.5 \%$ and $36.3 \%$ right thumb. In preparation containing triclosan $0.5 \%$ can reduce the amount of bacteria on the left thumb by $81.72 \%$ and $81.33 \%$ right thumb. Antiseptic power in the preparation with triclosan $1 \%$ can reduce the number of bacteria on the left thumb by $93.07 \%$ and $92.28 \%$ right thumb. We can conclude the gel preparation of hand sanitizer carbon can inhibit and reduce the growth of bacteria. 
Table 2. Univariate analysis group B (before and after washing hands use hand sanitizer)

\begin{tabular}{cccc}
\hline No & \multicolumn{3}{c}{ Amount Figures Bacteria } \\
\cline { 2 - 4 } Sample & Before & After & Difference \\
\hline 1 & 0 & 0 & 0 \\
2 & 0 & 0 & 0 \\
3 & 340,000 & 0 & 340,000 \\
4 & 490,000 & 0 & 490,000 \\
5 & 340,000 & 0 & 340,000 \\
6 & 0 & 0 & 0 \\
7 & 450,000 & 0 & 450,000 \\
8 & 300,000 & 0 & 300,000 \\
9 & 540,000 & 0 & 540,000 \\
10 & $1,030,000$ & 0 & $1,030,000$ \\
11 & 490,000 & 0 & 490,000 \\
12 & $3,260,000$ & 880,000 & $2,380,000$ \\
13 & $3,700,000$ & 0 & $3,700,000$ \\
14 & $6,940,000$ & 0 & $6,940,000$ \\
15 & $1,830,000$ & 0 & $1,830,000$ \\
\hline Amount & $19,710,000$ & 880,000 & $17,000,000$ \\
\hline Average & $1,314,000$ & 58,667 & $1,255,333$ \\
\hline Source
\end{tabular}

(Source: Primary Data, 2017)

In hand sanitizer substance contained disinfectant that is $70 \%$ ethanol, so hand sanitizer effective to kill or reduce bacterial. The result showed that the total number of bacteria after washing hands with hand sanitizer is lower than before washing hands with hand sanitizer that is reduced by $96 \%$.

Chemicals compound that kill bacteria are called bactericidal, while chemicals that inhibit growth are called bacteriostatic. Antimicrobial ingredients can be bacteriostatic at low concentrations, but are bactericidal at high concentrations. Inhibiting microbial activity, 50$70 \%$ ethanol acts as a denaturation and coagulates proteins, denaturation and coagulation of proteins will damage the enzyme so that microbes cannot meet the needs of life and eventually its activity stalled (Purwaningsih, 2015).

\section{Comparison Results of the Total Number of bacteria between Hand Washing using Soap and Hand Sanitizer}

Based on table 1 and table 2, the results of the bivariate analysis using test of independent sample obtained result: $\mathrm{t}$ count $=$ $2.23755>$ t $0.05(13)=2.16037$ concluded to reject $\mathrm{H}_{0}$, meaning that there was a difference of the total number of bacterial between washing hands using liquid soap and hand sanitizer in students of Medical Laboratory Technology Department, Health Polytechnic of Kendari.

Comparison of the results of the total number of bacteria includes washing hands with liquid soap and hand sanitizer seen the total number of bacterial in washing hand using soap is higher than with hand sanitizer. Total average number of bacteria using liquid soap 615,667 colonies per $\mathrm{ml}$ and the average of the number of bacteria using hand sanitizer 58,667 colonies per $\mathrm{mL}$. Difference in the total number of bacteria as many as 557,000 or $90 \%$. These results are consistent with research (Desiyanto \& Djanah, (2013) and Radji (2007), there were differences in the total number of bacteria between washing hands with flowing water, soap, hand sanitizer $\mathrm{A}$, hand sanitizer $\mathrm{B}$, and a control group (without washing hands). Hand sanitizer proved to be effective to the decrease in the number of bacterial numbers and descriptively the most effective are hand sanitizer B (alcohol 60\%). This research and other similar research show that hand sanitizer very effective to reduce and inhibit bacteria.

Liquid soap and hand sanitizer are effective for reducing the total number of bacteria. This is evidenced by the significant results between before and after hand washing going on the decrease in the total number of bacteria. The average result of the test of independent samples showed hand sanitizers are more effective in killing the bacteria because the effective value is higher than the number of bacteria after using the liquid soap that was $96 \%$ while the total number of bacteria after using the liquid soap that was $95 \%$.

Nevertheless, the habit of washing hands well using soap and hand sanitizers are both effective in lowering the total number of bacteria on the hands, because it is based on research of Cordita (2017) and Ramadhan (2013) that washing hands with antiseptic soap is more effective than washing hands with hand sanitizer, that is the effectiveness on decreasing in the number of bacteria with 
hand wash using hand sanitizer $60 \%$ and antiseptic soap equal to $73 \%$.

Maintaining hand hygiene is very important habit. Healthy is a gift of God to be grateful. Healthy is a human right that must be respected (Desiyanto \& Djanah, 2013). Microorganisms on the surface of the skin and around the environment can cause many infectious diseases in humans. This is where the role of antiseptic that serves as a killer or inhibition of the growth of microorganisms on the skin surface. It is very important to prevent infectious diseases (Levinson, 2008). Washing hands removes dirt and dust mechanically from the skin surface and significantly reduces the number of microorganisms.

Washing hands is a process that mechanically releases dirt and debris from the skin of the hands using water. Wash your hands is to wet your hands with running water to avoid disease, so that germs attached to the hands are completely lost (Ministry of Health Republic of Indonesia, 2008). The high effectiveness of washing hands can prevent the transmission of disease, so it is important to make efforts to improve washing hands habit.

\section{Utilization of Research Result as Learning Source}

The source of learning includes all the good sources of data, people or objects that can be used to provide facilities (ease) for learners. Therefore, the learning source is all the components of the instructional system both specifically designed and that can be used or utilized in learning activities. The results of this research are used as a learning resource that is as a research journal or research paper. Research journal is a research report that was done scientifically (Rosita et al., 2016; Sarimusrifah, 2016; Yuniarti, 2007). Research journal or paper is a substantial piece of academic writing, usually done as a requirement for a class, in which the author does independent research into a topic and writes a description of the findings of that research.
Basically, most research journals can be accounted for their scholarship depending on the method used in preparing reports of research journals. This research journals can also be used as a learning resource of the students at Medical Laboratory Technology Department, Health Polytechnic of Kendari.

The existence of the fit between the vision concept of the Medical Laboratory Technology Department produced by professional laboratory technology experts and superior in the field of microbiology and conformity with college curriculum based on Indonesia National Qualifiers Framework 2014 (in Indonesia known as KKNI), shows the concept of the result comparison the number of bacteria between washing hands using soap and hand sanitizer can support the need implementation of vision. Given the conformity of this concept, the results of the study can be used a material on the Total Plate Numbers (TPN) material to compare the number of bacteria Most Probable Number (MPN) in Bacteriology 2 for Students of the third semester.

\section{CONCLUSION}

There were differences in the total number of bacteria include washing hands with liquid soap and a hand sanitizer. Hand sanitizers are more effective to reduce the total number of bacteria than the liquid soap that is a difference of 557,000 colonies per $\mathrm{mL}$. As well as the application of research results regarding the comparison of the total number of bacteria include washing hands with soap and hand sanitizer as a learning resource for students at Health Polytechnic of Kendari, Medical Laboratory Technology Department that is designed in the form of research journal with competency standard in the subject of bacteriology that is capable of understanding how to identify bacteria and counting of the total number of germs.

To the next researcher is expected to do advanced research to know comparison the number of bacteria between washing hands by using some type of hand sanitizer and determine the type of bacteria present in the palm of the hand. 


\section{REFERENCES}

Cordita, R. N. (2017) .Perbandungan efektivitas mencuci tangan menggunakan hand sanitizer dengan sabun antiseptik pada tenaga kesehatan di ICU Dr.HABDUL MOELOEK. Bandarlampung: Fakultas Kedokteran Universitas Lampung.

Ministry of Health Republic of Indonesia (2008). Pusat promosi kesehatan dalam pencapaian PHBS. Jakarta: Ministry of Health Republic of Indonesia.

Desiyanto, F. A., \& Djanah, S. N. (2013). Efektifitas mencuci tangan menggunakan cairan pembersih tangan antiseptik (Hand sanitizer) terhadap jumlah angka kuman. Jurnal Kesmas, 2, 55-122. DOI: http://dx.doi.org/10.12928/kesmas.v7i2.1041

Levinson, W. (2008). Review of medical microbiology \& immunology. Tenth Edition. New York: The McGraw-Hill Companies, Inc.

Murray. (2005). Medical microbiology. $6^{\text {th }}$ ed. Canada: Mosby.

Retno, R. S., \& Yuhanna, W. L. (2016). The learning of science basic concept by using scientifiq inquiry to improve student's thinking, working, and scientific attitude abilities. Jurnal Pendidikan Biologi Indonesia, 2(1), 1-9. Retrieved from http://ejournal.umm.ac.id/index.php/jpbi/.

Rosita, D., Zaenab, S., \& Budiyanto, M. A. K. (2016). The analysis on the chlorine contents in rice circulation in pasar besar of Malang as the biological learning resource. Jurnal Pendidikan Biologi Indonesia, 2(1), 88-93. Retrieved from ejournal.umm.ac.id/index. php/jpbi/article/view/3386.

Shu, M. (2013). Formulasi sediaan gel hand sanitizer dengan bahan aktif triklosan 0,5\% dan 1\%. Calyptra: Jurnal Ilmiah Mahasiswa Universitas Surabaya, 2(1), 1-14. Retrieved from https://journal.ubaya.ac.id/index.php/ jimus/article/download/173/150.

Sibuea, W. H., Panggabean, M. M., \& Gultom, S. P. (2007). Ilmu penyakit dalam. Jakarta: Rineka Cipta

Sunarti, S. (2015). Effectiveness of hand wash to the decrese in number of germs on the visitor of badan perpustakaan daerah provinsi kalimantan timur. Jurnal Ilmu Kesehatan. Retrieved from ojs.stikesmuda.ac.id/index. php/ilmu-kesehatan/article/view/.

USAID Indonesia. (2009). Enviromental services project. Retrieved from
http://indonesia.usaid.gov/en/Activity.160.as px.htm.

Wahdiniati, L. (2016). The examinaton of Salmonella sp. and Escherichia coli content on fish-paste in Klampis market of Bangkalan Madura as biology learning resource. Jurnal Pendidikan Biologi Indonesia. 2(2), 198-205. Retrieved from http://ejournal.umm.ac.id/index.php/jpbi/.

Purwatiningsih, S. (2015). Pengaruh penggunaan hand sanitizer terhadap kepatuhan cuci tangan perawat pelaksana di ruang rawat inap RSU Assalam Gemolong, (Unpublished thesis). Surakarta: Stikes Kusuma Husada. Retrieved from http://digilib.stikeskusumahusada.ac.id/files/ disk1/23/01-gdl-sripurwant-1145-1-skripsih.pdf.

Qisti \& Rachmiati. (2009). Sifat kimia sabun transparan dengan penambahan madu pada kosentrasi yang berbeda. (Unpublished thesis). Bogor: Institut Pertanian Bogor.

Rachmawati, F. J., \& Triyana, S. Y. (2008). Perbandingan angka kuman pada cuci tangan dengan beberapa bahan sebagai standarisasi kerja di laboratorium Mikrobiologi Fakultas Kedokteran Universitas Islam Indonesia. Jurnal Logika, 5(1), 1410-2315. Retrieved from http://journal.uii.ac.id/index.php/ Logika /article/view/179/167

Radji, M., Suryadi, H., \& Ariyanti, D. (2007) Uji efektivitas antimikroba beberapa merek dagang pembersih tangan antiseptic. Majalah Ilmu Kefarmasian, 4(1), 1-6.

Ramadhan, I. (2013). Efek antiseptik merk hend sanitizer terhadap bakteri Staphylococcus Aureus. Jakarta: Universitas Islam Negeri Syarif Hidayatullah. Retrieved from http:// repository.uinjkt.ac.id/dspace/bitstream/123 456789/26361/1/IZKAR\%20RAMADHANFKIK.pdf.

Sarimusrifah, I. M. (2016). Buku penuntun praktikum bakteriologi. Kendari: Poltekkes Kemenkes Kendari Jurusan Analis Kesehatan.

Yuniarti, T. (2007). Penuntun praktikum bakteriologi. Kendari: Poltekkes Kemenkes Kendari

WHO. (2009). WHO guidlines on hand hygiene in health care: A summary. Geneva: World Health Organisation. Retrieved from http://apps.who.int/iris/bitstream/10665/701 26/1/WHO_IER_PSP_2009.07_eng.pdf.

Wati, R. (2011). Pengaruh pemberian penyuluhan PHBS tentang cuci tangan 
Darmayani et al / Jurnal Pendidikan Biologi Indonesia / 3 (3) (2017) pp. 258-265

terhadap pengetahuan dan sikap mencuci tangan pada siswa kelas V di SDN Bulukantil Surakarta (Unpublished thesis). Surakarta:
Fakultas Kedokteran Universitas Sebelas Maret. Retrieved from https://eprints.uns.ac. id/6069/1/197231711201109051.pdf. 